\title{
INTERVIEW WITH LEWIS RICARDO GORDON ENTREVISTA COM LEWIS RICARDO GORDON
}

\section{DOI: https://doi.org/10.20873/uft.2179-3948.2018v9n1p121}

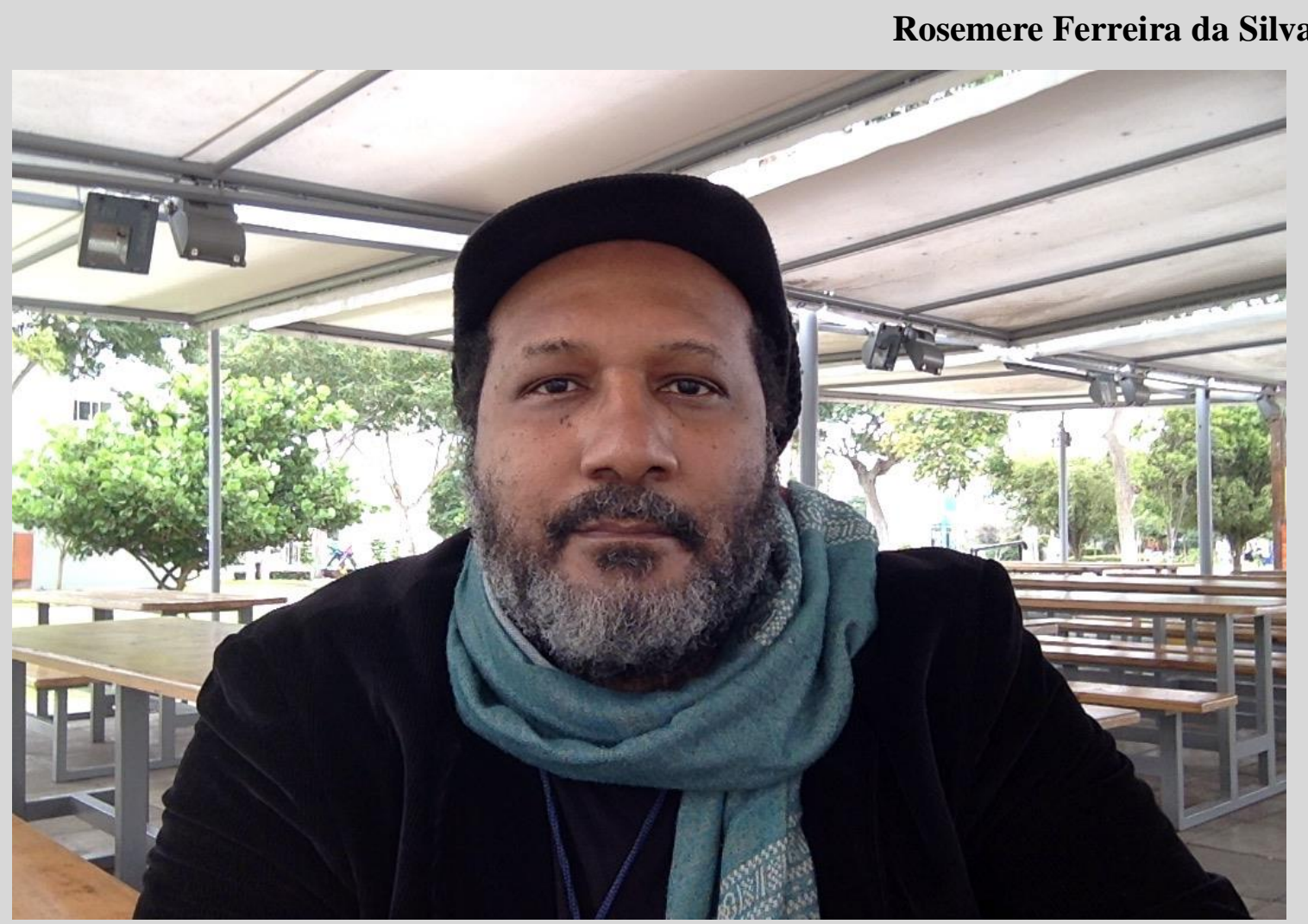

Lewis Ricardo Gordon, 2018. Foto de Rosemere Ferreira da Silva.

1- Dr. Lewis Ricardo Gordon would you discuss some aspects of your biography: where were you born, why are you in the United States, where did you study, where do you currently work, and what kind of work do you do?

I was born in Kingston, Jamaica in 1962. My mother left my stepfather in the late 1960s. My two maternal brothers and I followed from 1971 onward. We lived in the South Bronx in New York City, where we moved around quite a bit and ended up in the Northeast

\footnotetext{
${ }^{1}$ Professora de Literatura e Cultura Afro-Brasileira, História e Cultura dos Povos Indígenas e Leitura do Texto Literário na Universidade do Estado da Bahia (UNEB), Brasil, onde também coordena o grupo de pesquisa Literatura e Afro-descendência. E-mail: roserosefr2000@yahoo.com.br
} 
Bronx, where my mother lived till her death. I loved music and the sciences as a child, though I had a penchant for all things wondrous. I particularly loved archaeology, astronomy, and music. I went to Evander Childs High School without plans of going to college. I played jazz and blues professionally since my adolescent years. My then girlfriend was interested in becoming a school teacher. Her efforts and encouragement led us both to Lehman College of the City University of New York. I gave it a go to spend more time with her. Not sure where it would lead, I took courses I loved and some semesters registered for as many as eight classes. One of my philosophy professors, Bernard Baumrin, recommended me for a special program called the Lehaman Scholars Program. I wasn't initially interested, but one day I bumped into a pre-med friend who was interviewing for the program. When the professor opened his office door, I heard Charlie Parker's Bird at the Roost (1948) playing on a vinyl record. When I named the recording, the professor-a skinny, thoughtful White Jewish man in light beige pants, a white shirt with black tie, and a dark blue jacket-was curious. He asked me to wait. After meeting with my friend, the professor asked me to come in, and he and I ended up speaking for a few hours. I decided to apply to his program. His name was Gary Schwartz. He was a professor of classics and director of the Lehman Scholars Program. That was in the fall of 1981. We've been close friends — in truth, Family — ever since. He is, as far as I'm concerned, family. I ended up studying classical literature with him, philosophy, and political science with others, though I hadn't thought about a major. The joy of learning was enough for me. Taking so many classes meant I was eligible to complete my degree two years later. I decided to declare majors where I had the majority of my credits and ended up writing three honors theses and graduated, because of my courses in the sciences and language requirements, as a member of the academic honors societiesPhi Beta Kappa and Pi Sigma Alpha. I subsequently played music and did substitute teaching in New York City, which required my taking graduate courses in education and securing a masters degree. I took advantage of whatever free courses I could secure, which included nine credits in economics at the New York Federal Reserve through the City University of New York's graduate education program at Queen's College. During those years I had founded The Second Chance Program at Lehman High School. It was a program designed for in-school truants. I was informed that the students were so difficult that if even ten percent of them completed high school the program would 
be a success. Our rate was eight-five percent. My observation that respecting people's humanity makes them grow, while failing to do so makes them wither, led to intense philosophical reflection on human potential. I loved writing throughout my childhood and that continued during and after college. I thus decided that since I needed to pursue more intense discussion on the human being's relationship to reality, as well as questions of human potential, I should pursue a PhD. Given my way of thinking, which brought the arts and sciences together, my friends and former professors recommended Yale. I applied. I was offered admission. I accepted, and the rest was history. I had the good fortune to complete my degree with Maurice Natanson as my advisor and Jonathan Smith and M. Sean Copeland on my committee. Natanson was a student of the great philosopher, sociologist, and jurist Alfred Schütz. Smith was a giant in American philosophy and Hegel Studies. He worked with people such as Bertrand Russel, Ernest Nagel, and Hans-Gorg Gadamer. Copeland was one of the theologians and philosophers who formed Womanist theology, and she was a scholar of Black Liberation theology, existentialism, and political theology. Her mentors includedJaramogi Abebe Agyemanand James Cone. I spent three and a half years at Yale, achieving my doctorate with distinction in the spring of 1993. My dissertation was entitled "Bad Faith and Antiblack Racism: A Study in the Philosophy of Jean-Paul Sartre."

2- Talk a little about your relationship with philosophy. Did you choose philosophy or has philosophy chosen you? Who are your main references in this field of knowledge?

The two aren't mutually exclusive. When we find what we should be doing, we retrospectively realize we've been doing it all along. My first experience with philosophy, I realized many years later, was when I was a child of about five years of age. I remember lying down on the grass at night in a soccer field in Kingston, Jamaica. That was the mid1960s. There were fewer lights even in Jamaica's biggest city back then. That meant the sky was majestic. So many stars. I've never forgotten that. It was my first experience of genuine wonder. I began to notice so many things around me. It led to my curiosity about life, nature, reality. I continuously inquired into more. I was curious about 
everything - the soil and the life teaming within it; the sky and what was out there beyond the stars; the paradox of sensed invisibility; and so on. Philosophy made sense to me because it demanded asking more. So, although I was already such a path, the journey was highly existential and phenomenological. I was choosing that which had already been chosen, I later realized. A strange responsibility was there in each effort to think further. Ironically, this radicality of thought also means I am not a philosophy nationalist. As you already know, I take the position that philosophy only lives when we are willing to go beyond it.

3- You are a specialist in the thinking of Frantz Fanon. How can Fanonian thinking be important for Brazil as a reference in intellectual work and research?

Fanon's thought is manifold. He rejected the ontologizing or cording off of human reality. We're endangered, he argued, when we forget that human institutions are created by human beings. When we forget that, we treat our institutions as unchangeable even though their maintenance depends on us. Fanon also argued that it is important to become what he called "actional." That means being agents of history. People become agents of history when they understand they are not gods and that no time in the past was perfect. That means that history is a constant struggle of trying to make things better while many attempt to reach a point of closure. Many people attempt to say, "History ends here." Yet "here" always entails a "there." Fanon called for moving on. Fanonian thinking is important for Brazil because it is important for everyone. Humanity is not in a state of perfection; there is much work for us to do while realizing that although we can never be "perfect," we can become better or at least try. Fanon also addressed clear concerns of Afro-or Afri-modernity. Colonialism, enslavement, and racism obscured history through claiming that black people are only effects of white people's actions. I call this "black melancholia." It is where black people see ourselves as indigenous to Euromodernity andnot belonging to it. We are homeless in a world to which we are temporally indigenous. Fanon, and others such as Cheikh Anta Diop, Almícar Cabral, el-Hajj Malik el-Shabazz (Malcolm X), and Ella Baker took the position that black people should build a world to which we belong on our own terms. They in effect argued for the transformation of black 
people into Black people. The first are effects; the second are agents of history. I think Black Brazilians and indigenous Brazilians could learn much from this. Fanon also argued that people must cultivate skill sets that are organic to the struggles they face. That means every generation has its mission. Brazilians of today must think through what their obligations are to Brazilians of tomorrow. In that stands their historic mission.

4- Among a series of intellectuals that you use as reference in your works, the Brazilian Paulo Freire is highlighted. How does Freire's thinking fit into your intellectual production?

I see Freire as phenomenological with an attunement to maturity. His critical pedagogy was inspirational when I worked as a high school teacher in New York City. I was inspired by his ideas - in addition to those on education offered by Antonio Gramsci, John Dewey, Frantz Fanon, and Angela Y. Davis. I teach a course called "Radical Theories of Education," in which we study their ideas. A lot of Freire's ideas were already there in what could be called the Black Radical Tradition. His theory of conscientização is similar to Kwame Nkrumah's theory of Consciencism and Gramsci's on critical consciousness. He also shares Fanon's view that such a consciousness entails a maturation process in which one's relationship to reality is demystified. What I like about Freire's thought is that it is attuned to reality. It also informs my understanding of research and scholarship. For me, an expert is ultimately an advanced student. She or he is someone who fell in love with learning and never stopped doing so. This understanding of what we do as continued, committed learning makes all intellectual work educational when done well. I should add, however, that "educational" for me isn't exclusively pragmatic. It involves the multifaceted dimensions of our relationship with reality. This includes, as well, our ability to appreciate reality's beauty and understand its ugliness; it involves joy and sorrow; the known and the mysterious.

5- Much has been discussed and proposed about the "new functions" of the intellectual in the Human Sciences. In your opinion, what is the contemporary challenge of the intellectual?

I don't think there is one challenge. There are many. These challenges includ the following isues: the danger of market colonization, not only of knowledge but also of 
politics; the ongoing struggle against seductive forms of stupidity; the fetishization of ignorance; the pathological fear of reality and truth; the insipid and growing domination of the view that nothing new can be thought; and, in short, nihilism. I have discussed various dimensions of these in my writings. To do so here would take up the rest of the interview. Here are some summaries: capitalism requires nothing out of its reach. Thus, intellectuals become subordinated to capitalism by struggling to make themselves "marketable." One way these days is to increase their marketability through claims of being "political." This is in effect the market colonization of politics and explains is an explanation of why many so-called political intellectuals offer no organic solutions, but instead sometimes only present textual links to political reality. They embody the contradiction, offering their political identities as marketable, to the extent to which they do not make that identity compromise their marketability. Anti-intellectualism is one of the seductive forms of stupidity. There is no shortage of intellectuals who claim to be anti-intellectual. It's one of the doorways to fascism; fascists valorize their stupidity as a kind of mass consciousness. The fear of reality and truth already permeates many societies with subjective language, as though all issues come down to subjectivity versus objectivity. Reality doesn't care whether we are subjective or objective, and in truth such arguments are dead ends: there is no subjectivity without objectivity and vice versa. Sadly, the descent has worsened. Too many people don't think anymore; they "feel." The growing, ultimately narcissistic rage against novelty of thought is linked to the demise of Eurocentrism. The presumption is that when Europeans or whites run out of ideas it must be because developing new ideas is no longer possible. That's another version of Europe and whites as the end of history. Well, the rest of us cannot afford that. We've got to move on and think creatively. All this is nihilistic. It makes intellectual life meaningless. It also achieves its misguided ends by demanding proof of novelty before ideas have been thought. This is a fallacy. We never have advanced knowledge of what we can do. Much of life, of the thinking it entails, involves imagining and doing what wasn't done before. The challenge, then, is to rally the existential paradox of commitment without guarantees. 
6- Although Brazil has advanced in the discussion about racism, it is widely perceived that racism continues to operate in the oppression of black people. Can you, from your studies, systematize a way out of the Brazilian racism case?

Racism is a political phenomenon. It therefore requires political solutions. The best way to get out of racism is through committed action from those who are its advisaries. Those actions involve building institutions in which human beings could live in non-racist social relations. This requires a different understanding of what human beings are and can be. If we treat ourselves as permanent or unchangeable, then we would just have racists in different social environments. If we understand ourselves as those relationships, then creating different social relationships and institutions entails the birth of different kinds of human beings and the social worlds in which they live.

7- In Brazil, there is still the mistaken belief that the black individual who socially ascends does not face any more racial problems. To what extent can the imbrications between race and class be clarified in order to avoid the fallacy that the rise of the black individual is an exception?

This question relates to the previous one. If racism is a political phenomenon, it is also a social one. Race never exists in a vacuum. It is a function of many converging forces. A race by itself is an abstraction. So is a class. A gender. A sexual orientation, and more. Those are all abtractions. Living human beings are convergences of these relationships. Thus, different elements manifest themselves in different ways as they are connected to other social situations. The old model of treating a human being as a thing imagines one could pick up a black woman, for example, and place her in a place that was historically designed to exclude her and the problem is then fixed. What such proponents don't get is that if the system was designed to exclude her, it could only let her in as an affirmation of her exclusion. Put differently, she would only be there as an "exception," which in effect would make her function as the maintenance of that system. She would then simply be a white man who only looks like a black woman. Now if we understand her as a set of relationships, the whole scenario changes. For her to enter means the array of baggage connected to her must also enter. They include the history of racism, sexism, classcism, 
etc. Since those are incompatible with maintaining the system designed for their exclusion, it means new relationships must follow. It means a different kind of system, one not premised on exclusions, must emerge. That, however, requires also changing those people for whom the exclusions- based on race, class, or sex- were designed to benefit.

8- Black feminist thinkers in the United States have initiated made specific discussions about the intersections between race, class, gender and sexuality. Taking into consideration your academic experience in other countries, how do you see the global importance of the work developed by black and feminist intellectuals?

Black feminism is, in my view, a misnomer in some contexts and accurate in others. Where it means an imitation or mimicry of white feminism, it's a misnomer. Where it means the world of dignity and freedom for which Black women have struggled regardless of the terms to which they are referred, it is accurate. One of the things about Black feminism in the United States is that its history is often misrepresented. Black feminist activism began in every moment of defiance Black women, enslaved and otherwise, were engaged in from the moment they landed in the Americas. It's there in the revolts they led, the enslaved people they guided to territories in which slavery was illegal, and in their speeches and writings. Sojourner Truth, Lucy Parson, and Anna Julia Cooper are great examples from the 19th century. Cooper lived well into the 20th. And there are many others. Today much discussion of Black feminism is dominated by its academic exemplars. Kimberlé Crenchaw's work on intersectionality has gained world prominence, though the insights go back not only to ideas from Anna Julia Cooper to Angela Y. Davis, but also to writings of Black men such as Martin Delany through to Thomas Isidore Noël Sankara as well. It's fashionable to construct discussions of Black men as antipathetic to Black feminist thought, but that is not historically correct. Yes, there were and continue to be Black male sexists, but the fact of the matter is that the history of Black female leadership not only in the Americas, but also in continental Africa is such that very different paradigms of Black women and men on such issues need to be admitted and addressed. Some theorists, such as Keisha Lindsay, Nikiru Nzegwu, 
Oyèrónké Oyĕwùmí, Lyn Ossome, and Hanétha Vété-Congolo, have raised these concerns. I discuss some of the global impact of the intellectual work offered by Black feminist philosophers in my book An Introduction to Africana Philosophy, but beyond intellectual history is also the reality of the multiple forms of work Black feminists do. They include not only the world of pedagogy and scholarship —of which you, for instance, are a part - but also other facets of social life. I am thinking of women such as Amanda Alexander, who founded the Detroit Justice Center, and Alicia Garza, who co-founded many organizations, including Black Lives Matter. There is the work of community builders, political workers, farmers (of which women are the highest number in Africa, for instance), physical and spiritual healers, mothers, and also, more controversially, sex workers. The last are part of the world of shadow economies whose political significance, especially with regard to rethinking agency in service economies, calls for reflections. In short, too many think of feminist work-and indeed much committed work-too narrowly. Rethinking what that involves could lead to better understandings of what constitutes contribution and who contributes.

9- In your book An Introduction to Africana Philosophy (2008), you argue about the importance of Africana Philosophy as a modern philosophy. What relationships can be established between Africana Philosophy and other disciplines such as History, Literature, Political Science, Sociology, Anthropology, etc.?

I argue that Africana philosophy, which is another way of saying African diasporic philosophy, is modern because the idea of the African diaspora emerged through Arab enslavement and then the European efforts across the Atlantic and East Indian oceans. I interrogate the concept of "modern" in my recent writings, where I point out that its content involves mechanisms of power through which people "belong" to the future. This means that modern peoples have emerged throughout history. What was been different since 1492 is the emergence of Euromodernity. This one differs from others in that its model of belonging was racialized. Race and racism constitute its philosophical anthropology. There was and continues to be, however, resistance. Those involving the cultivation of belonging to the future outside the framework of Euromodern mimicry are building their own modernities. This includes Afro- or Afri-modernity. It is one of the 
bases for the transition from black to Black. The relationships between Africana philosophy and other disciplines is manifold. I argue that Africana philosophy raises at least three challenging questions: (1) What does it mean to be human? (2) What are freedom and liberation? And (3), What must be done to address the crises of reason raised by the emergence of racist rationality? Reformulated, this third comes down to the question of whether justification is any longer justifiable. I call this "the metacritique of reason." The first addresses racism directly. The second addresses colonialism and enslavement, among other forms of institutional oppression. The third, however, addresses disciplines as well. If any discipline is presumed legitimate without interrogation, it can collapse into a colonial epistemological force. There is, therefore, a form of humility in Africana philosophy. It must communicate with other sciences instead of imposing itself upon them or absorbing them into itself as their legitimate overlord. The metacritique of reason is, then, a form of teleological suspension of disciplinarity. This is a formulation I pose in my book Disciplinary Decadence (2006). It involves examining the danger of forgetting that human beings create disciplines, which are developed to address specific problems inherent to our relationship to reality. Since only a god could create a discipline that encompasses everything, there is a fundamental incompleteness at the heart of every human disciplinary practice. This means a discipline must be willing to go beyond itself for the sake of communicating with others in an efforts to cultivate relationships with reality. In philosophy, I call this a teleological suspension of philosophy. It means being willing to go beyond philosophy for the sake of reality. Every discipline, then, is a practice of continued learning along with other disciplines. Failure to understand this leads also to what I call methodological fetishism. This is where the method is also treated as created by a god. It leads to the naive conclusion that one need simply apply the method as thought, or one shoe that fits all. The implications of this critique are many. A crucial one is that the various constellations of disciplines at our disposal may only tap into a small fragment — a tiny point —of disclosing our relationship to reality.

10- Your next book will be about social justice. At this ruthless political moment that reflects the demise of democracies, especially in South America, how can human existence, freedom of thought and social justice be apprehended from the perspective of existentialist philosophy? 
Actually my next three books are on Black consciousness, on Global Existentialism, and a collection of essays on Africana phenomenology. After those, I plan to write a book on the study of Jews of color and then a book on concepts of justice indigenous to our epoch. I will argue that social justice approaches are insufficient to address problems of the colonization of normative life. I outline that argument in my chapter, "When Justice Is Not Enough," which was recently published in the anthology I co-edited with Fernanda Bragato entitled, Geopolitics and Decolonization (2017).

11-Different academic and non-academic communities all over the world have used your theoretical work to develop research on the specificities of your thinking. This special issue of EntreLetras is about the global significance of your intellectual production, and it is the first time in Brazil that surch a journal has been exclusively devoted to your work. What kind of message would you like to leave for young Brazilian researchers?

Think about the aforementioned challenges to intellectual life. An addition is the form of decadence that attempts to lock people of the Global South in the realm of experience with thought left in the hands of dominating, Eurocentric forces of the North. That would make experience dark and thinking white. That would be a form of epistemic dependency. It is a form of epistemological colonialism. The struggle for dignity, freedom, and liberation involves also taking responsibility for how we think and bring meaning to thought and systems of knowledge. This makes intellectual work crucial. It's one of the reasons there are market efforts to colonize it. Brazilian researchers should, like all committed and excelente intellectuals, open the door of thought through which life flourishes. Think about what needs to be thought. This requires the courage to face knowledge, life, and the welfare of us all with the commitment to face truths that few can bear. Start from the premise of valuing what is not often valued: each other. We have inherited a world that formulates value as something offered from those who degrade, dominate, and oppress us. If we accept that, then we would fail to see the value offered from each other. And if we stop there, we would fail to see the value of being valued by each other. This purposely awkward formulation is to raised to highlight a central point. Looking into the past, too many of us seek sources of value from kings, queens, generals, 
and capitalists. It is revolutionary, however, to value the love offered down the ages from the colonized, the enslaved, the once invisibilized. Those are the people whose courage and commitment were the conditions enabling us to fight different kinds of struggle today. We should do the same for our descendants. We don't serve the interests of our ancestors of progeny by extinguishing the flame that inspired our love of learning. We must admit we don't know where that road will lead and, instead, ask about journeys worth making. Not because of what we will gain but what, in the practice of so doing, exemplifies the best of what we are, and ultimately we may learn and appreciate, who we are as well.

Interviewed by Dr. Rosemere Ferreira da Silva in July 2018. 